\title{
Makna Konotasi dan Denotasi dalam Lirik Lagu 'Himalaya' karya Maliq D'essentials
}

\author{
Khairunnisa Lubis ${ }^{1, *}$ M. Ichasan Ardhian ${ }^{2}$ Dina Ulva Jelita Rumahorbo ${ }^{3}$ Frinawaty \\ Lestarina Barus ${ }^{4}$ \\ Universitas Negeri Medan 1,2,3,4 \\ *Corresponding author. Email: nisakhairun200@gmail.com
}

Submitted: 10 May 2021

Revised: 12 July 2021

Accepted: 5 Dec 2021

\begin{abstract}
Song lyrics are a medium for expressing one's feelings that are poured in written form and have an aesthetic value in the expression. Song lyrics not only convey messages openly, but also have hidden meanings. This study examines the meaning of the lyrics of the song entitled "Himalaya" sung by Maliq D'Essentials. This study uses a semantic approach to interpret the meaning of word order. The method used in this study is a qualitative descriptive method. The data collection technique used is the listening and note-taking technique. The lyrics of the song entitled "Himalaya" is the subject of research and the meaning of the song as the object of research, which in this study we will know that the overall denotation meaning of this song expresses the author's desire to imagine future events. The Himalaya song features a lot of wish-if sentences. The meaning of this song imagines the writer's desire to be with someone in the future. Meanwhile, the connotative meaning of the song shows the writer's ability to deal with any kind of situation.
\end{abstract}

Key words. semantics, denotation, conotation, meaning

Abstrak. Lirik lagu merupakan media ungkapan perasaan seseorang yang dituangkan dalam bentuk tulisan dan memiliki nilai estetika pada ungkapan tersebut. Lirik lagu tidak hanya menyampaikan pesan secara terang-terangan, namun juga ada makna terpendam. Penelitian ini mengkaji pemaknaan pada lirik lagu berjudul "Himalaya" yang dinyanyikan oleh Maliq D'Essentials. Penelitian ini menggunakan pendekatan semantik untuk menafsirkan pemaknaan dari susunan kata. Metode yang digunakan dalam penelitian ini adalah metode deskriptif kualitatif. Teknik pengumpulan data yang digunakan adalah teknik simak dan catat. Lirik lagu berjudul "Himalaya" adalah subjek penelitian dan pemaknaan dari lagu tersebut sebagai objek penelitian, yang mana dalam penelitian ini akan kita ketahui bahwa secara keseluruhan makna denotasi pada lagu ini mengungkapkan keinginan penulis untuk membayangkan kejadian di masa depan. Lagu Himalaya ini menampilkan kalimat berandai - andai yang cukup banyak. Pemaknaan lagu ini membayangkan keinginan penulis bersama seseorang saat di masa depan nanti. Sementara itu, makna konotasi pada lagu menunjukkan kemampuan penulis dalam menghadapi situasi yang seperti apapun.

Kata kunci. semantik, denotasi, konotasi, pemaknaan

\section{Pendahuluan}

Lagu merupakan media ungkapan perasaan seseorang yang dituangkan dalam bentuk irama dan tuturan serta memiliki nilai estetika pada ungkapan tersebut. Ungkapan perasaan tersebut dapat memuat perasaan sedih, bahagia, kecewa ataupun unsur perasaan emosinal 
lainnya. Cara menyampaikan perasaan pada lagu juga dipengaruhi oleh tujuan agar pendengar lagu ikut tersulut emosi ketika mendengarkan lagu tersebut.

Sylado (1983) berpendapat lagu merupakan aransemen musik dengan tambahan lirik berupa tulisan yang berisikan ungkapan perasaan dan pikiran penciptanya melalui cara-cara tertentu yang bersifat umum. Maka dari itu, lirik dan lagu adalah dua hal yang berkaitan. Lirik dalam lagu bersifat komunikatif dan berisi pesan yang imajinatif. Hal ini disebabkan lagu merupakan salah satu alat komunikasi yang memiliki nilai keestetikan di sana.

Berdasarkan dua pendapat di atas, maka dapat disimpulkan bahwa lagu merupakan media dalam menyampaikan dan menyalurkan perasaan maupun suasana hati ke dalam bentuk tuturan irama yang memberikan nilai setetika dengan menambahkan usnur tulisan di dalamnya sebagai pesan di dalam lagu tersebut.

Lirik lagu merupakan ekspresi seseorang tentang suatu hal yang sudah dilihat, didengar maupun dialaminya. Luxemburg, Ball dan Weststeijn (1984) menyebutkan mengenai teks-teks puisi tidak hanya mencakup jenis-jenis sastra melainkan juga ungkapan yang bersifat pepatah, pesan iklan, semboyan-semboyan politik, syair-syair lagu pop dan doa-doa. Jika definisi lirik lagu dianalogikan sama dengan puisi, maka harus diketahui apa yang dimaksud dengan puisi. Puisi merupakan rekaman dan interpretasi pengalaman manusia yang penting dan digubah dalam wujud yang berkesan (Pradopo, 2010). Kesimpulan yang dapat diambil bahwa ungkapan teks puisi juga terdapat pada lirik lagu yang berisikan pengalaman manusia yang diwujudkan melalui sebuah lagu.

Himalaya adalah sebuah judul lagu yang dinyanyikan oleh Maliq \& D'Essentials yang dirilis pada tanggal 15 Mei 2014. Lagu ini merupakan salah satu dari album Musik Pop Maliq \& D’Essentials. Lema Himalaya di sini merujuk kepada gunung tertinggi di dunia. Penggambaran lagu ini menggunakan objek "Himalaya" sebagai bentuk usaha seseorang untuk mendapatkan seseorang yang ia cintai. Hubungan kata "Himalaya" dan usaha bahwa ada usaha yang sangat besar dalam meyakinkan seseorang tersebut. Penggunaan kata "Himalaya" sebagai salah satu makna konotasi menggunakan majas hiperbola. Lirik ini juga meyakinkan seseorang untuk menjalani sebuah hubungan sampai berhayal ke masa depan. Ungkapan lagu ini mengekspresikan bahwa kesungguhan seseorang dalam menaklukkan seseorang.

Bait lagu tidak hanya menyampaikan pesan secara terang-terangan, tetapi ada pemaknaan kiasan di sana. Penyampaian dengan makna kiasan ini merupakan bagian dari makna konotasi, Sedangkan pemaknaan sebenarnya merupakan makna denotasi. Penyampaian makna menggunakan permainan bahasa untuk menambah kesan keindahan pada lagunya.

Menurut Awe (2003) permainan bahasa dapat berupa permainan vokal, gaya bahasa maupun penyimpangan makna kata dan diperkuat dengan penggunaan melodi dan notasi musik yang disesuaikan dengan lirik lagunya sehingga pendengar semakin terbawa dengan apa yang dipikirkan pengarangnya. Lagu Himalaya akan dikaji melalui pendekatan kajian semantik dalam ruang lingkup pemaknaan konotasi dan denotasi pada lagu Himalaya Maliq D’ Essentials. Lagu ini akan dianalisis tiap bait lagunya dalam pemaknaan lagunya.

Perbedaan yang paling mencolok antara penelitian ini dengan penelitian yang telah lalu ada pada pemaknaan yang dilakukan pada lirik lagu ini dimana pada penelitian ini menganalisis kajian makna konotasi dan denotasi berdasarkan pada nilai rasa yang terdapat dalam lirik lagu Himalaya Maliq D'Essentials. Makna konotasi sebuah kata memiliki perbedaan pada setiap pemaknaan di lingkungan masyarakat disesuaikan dengan pandangan hidup dan norma-norma penilaian kelompok masyarakat tersebut. Sedangkan makna denotasi bersifat memiliki rasa baik 
positif maupun negatif. Jika tidak bernilai rasa dapat juga disebut berkonotasi netral pada kata tersebut. Pada penelitian terdahulu hanya dibahas pemaknaan secara keseluruhan, sedangkan pada penelitian ini lebih terfokus pada makna yang terdapat pada setiap bait lirik lagu Himalaya dari Maliq D’Essentials.

Penelitian terkait pemaknaan pada lirik lagu ini sesungguhnya sudah pernah ada sebelumnya, namun terdapat berbagai perbedaan yang ditemukan jika dibandingkan dengan penelitian-penelitian yang sebelumnya. Dalam penelitian berjudul "Analisis Semiotika Makna Kerinduan Pada Lirik Lagu "Hanya Rindu" karya Andmesh Kamaleng" yang dilakukan oleh Adi, dkk menyimpulkan bahwa dalam lirik lagu tersebut terdapat makna denotasi yang menyampaikan perasaan rindu yang sangat besar kepada Ibunya, kemudian mereka menyimpulkan bahwa makna konotasi dalam lirik lagu tersebut yaitu rasa penyesalan yang mendalam, serta makna mitos yang menyatakan bahwa lirik lagu tersebut menjadi saluran penyembuh rasa rindu. Sementara itu, dalam penelitian terhadap lirik lagu "Lathi" yang dilakukan oleh Antika, dkk. Dalam penelitian ini penuli yang hendak mendalami makna konotasi, denotasi dan mitos juga membahas mengenai jenis-jenis makna lainnya di luar daripada ketika pemaknaan tersebut. Sedangkan dalam penelitian yang dilakukan oleh Henny, dkk terhadap lirik lagu "Rembulan" karya Ipa Hadi Sasono, yang mana selain pemaknaan dalam bentuk makna denotasi, konotasi dan simbol mereka juga menyajikan wujud verbal dan nonverbal.

Penelitian ini dilakukan berdasarkan pengamatan penulis terhadap sebuah lirik lagu berupa ungkapan makna baik makna denotasi maupun makna konotasi. Penelitian ini bertujuan untuk menambah pemahaman penulis serta pembaca dalam memaknai sebuah ungkapan dari dua aspek makna yaitu denotasi dan konotasi. Lagu 'Himalaya' dari Maliq \& D' Essentials sebagai subjek penelitian untuk dikaji ungkapan makna pada tiap bait lirik lagu.

\section{Metode}

Penelitian ini termasuk ke dalam penelitian kualitatif karena meneliti data yang berbentuk non-angka dan tak dapat dihitung nilainya secara pasti. Metode yang digunakan dalam penelitian ini adalah metode deskriptif karena di dalam melakukan penelitian ini, dilakukan dengan tujuan untuk menemukan secara tepat aspek pemaknaan konotasi dan denotasi dari lirik yang terdapat dalam suatu lagu serta ada-tidaknya hubungan antara kedua aspek tersebut. Hubungan yang dimaksudkan bukanlah hubungan sebab-akibat, melainkan hubungan yang lebih menuju kepada variabelitas.

Metode pengumpulan data yang digunakan adalah metode simak dan dilanjutkan dengan teknik catat. Peneliti menyimak lirik lagu Himalaya dengan melakukan pengamatan mendalam dan berulang. Selanjutnya, peneliti mencatat hasil observasinya ke dalam format data. Format yang disusun berisi item-item tentang kejadian atau tingkah laku yang akan terjadi. Item-item yang dimaksud disini adalah lirik lagu yang dianalisis, unsur makna denotasi dan konotasi yang terdapat di dalam lirik lagu tersebut. Lirik yang terdiri atas beberapa bait akan dianalisis perbait untuk ditemukan unsur denotasi dan konotasi di dalamnya, kemudian dimasukkan ke dalam bentuk tabel sehingga menjadi bentuk data yang lebih mudah dipahami.

\section{Hasil dan Pembahasan}

Dalam sesi berikut ini akan disajikan pembahasan mengenai kajian makna atas setiap kata yang memiliki pemaknaan, baik itu secara denotasi maupun secara konotasi. Setiap bait dalam 
lirik lagu akan dibedah untuk kemudian ditemukan pemaknaan katanya. Baik itu makna konotatif ataupun makna denotatif akan ditunjukkan dan dijelaskan secara rinci, sehingga benarbenar menunjukkan pemaknaan yang dimaksudkan kepada penulis.

\section{A. Makna kata "Himalaya” secara Umum}

Himalaya berasal dari bahasa Sanskerta yakni himá (salju) dan ā-laya (tempat/kuil). Secara geografis, Himalaya merupakan pegunungan tempat tumbuhnya gunung-gunung tertinggi yang membentang antara negara Nepal, China, Bhutan dan Pakistan. Gunung Everest $(8848 \mathrm{~m})$ sebagai gunung tertinggi di dunia merupakan salah satu bagian pegunungan Himalaya. Oleh karena itu, Himalaya identik dengan pemaknaan "tertinggi, dingin, perjuangan sulit dan besar".

Pemilihan kata "Himalaya" sebagai judul merupakan rujukan sebagai perjuangan tertinggi dan terberat. Tokoh dalam lirik menyatakan akan menjelajahi Himalaya demi sebuah cintanya. Pernyataan ini tidaklah bermakna literal karena memiliki si tokoh tidak benar-benar pergi ke Himalaya. Si tokoh hanya menggunakan asosiasi Himalaya untuk menunjukkan seberapa besar dan gigih usahanya dalam meraih cinta yang diperjuangkannya. Hal ini dibuktikan dalam keseluruhan lirik yang menekankan perjuangan si tokoh tersebut.

Dari penjabaran di atas, maka kata Himalaya termasuk kepada makna konotasi karena menunjukkan asosiasi yang terkait dengan kata Himalaya itu sendiri. Barthes pada buku Cultural and Communication Studies (2007) menjelaskan bahwa terdapat 2 pemaknaan dari sebuah ekspresi bahasa yakni makna denotasi dan konotasi. Barthes mengembangkan pemaknaan melalui semiotika menjadi dua tingkatan tanda, yaitu tingkat denotasi dan konotasi (Rusmana, 2014). Barthes (dalam Fiske, 2007) mendefinisikan makna denotasi sebagai landasan kerja Saussure yang mengacu dengan anggapan umum dan makna menjelaskan tentang tanda dengan memiliki perbedaan dalam konotasinya. Pemaknaan berikut ialah konotasi. Barthes menjelaskan bahwa konotasi sebagai suatu sistem yang terdiri dari penandapenanda, petanda-petanda, dan proses yang menyatukan sistem yang kedua (signifikasi) yang terbentuk dari tanda-tanda dalam sistem denotatif (Barthes, 1968). Barthes (dalam Hoed, 2011) memandang manusia dalam memaknai suatu hal tidak sampai pada pemaknaan denotasi, tetapi manusia menggunakan kognisinya melalui beberapa pemaknaan dan penafsiran yang disebut makna konotasi.

Barthes (dalam Rusmana, 2014) makna denotasi merupakan tanda yang penandanya mempunyai tingkat kesepakatan yang tinggi yang menghasilkan makna sesungguhnya. Pemaknaan kata "Himalaya" pada wujud nyata telah dijelaskan secara dasar pada pembahasan awal bahwa Himalaya merupakan tempat gunung tertinggi di dunia. Barisan pegunungan ini berada di Asia dan memisahkan Benua India dan Dataran tinggi Tibet. Secara Etimologi, Himalaya memiliki arti "tempat kediaman salju" dalam bahasa sanskerta berarti tempat kediaman. Maka dari itu, ungkpapan judul lagu ini menganalogikan tempat kediaman tertinggi ini sebagai ungkapan isi hatinya. Berlawanan dengan makna denotasi, Barthes (1968) konotasi merupakan penanda-penanda yang terbentuk dari tanda-tanda sistem denotatif. Fiske menjelaskan bahwa konotasi bekerja pada level subjektif yang tidak kita sadari secara sadar maknanya (Fiske, 2007). Pemaknaan judul "Himalaya" bukan hanya memiliki arti sebagai gunung tertinggi. Pemaknaan gunung tertinggi yaitu Himalaya akan ditaklukkan oleh penulis lagu gambaran wujud dari usaha seseorang yang benar-benar serius dalam menaklukkan pujaan hati. 


\section{B. Makna Tiap Bait Lagu “Himalaya” karya Maliq D'Essentials}

Sesuai dengan tatanan pertanda pertama, yaitu denotasi yang telah dikemukakan oleh Barthes, maka denotasi merupakan landasan kerja Saussure. Berikut ini akan disajikan hasil analisis yang menunjukkan bahwa di dalam setiap bait lirik lagu "Himalaya" oleh Maliq D'Essentials, yaitu tatanan yang menggambarkan relasi antara penandan, yang membentuk taraf ekspresi dan petanda yang memiliki taraf isi di dalam tanda dengan relevannya dalam realitas eksternal. (Barthes, 1968)

Selain makna denotasi, tentu akan disajikan pula makna konotasi pada bagian-bagian dalam setiap bait lirik lagu "Himalaya" oleh Maliq D'Essentials ini. Dalam teori R. Barthes, makna konotasi merupakan tatanan kedua yang menggambarkan interaksi yang berlangsung, dimana tanda bertemu langsung dengan perasaan atau emosi penulisnya serta nilai-nilai kukturalnya. Bagi Barthes, bahwa konotasi merupakan bagian manusiawi yang meliputi emosi dari objek yang ada di dalam sebuah bingkai. Pemaknaan tiap bait lagu ini juga menggunakan teori Barthes dengan memaknai lagu menggunakan makna konotasi dan denotasi. Berikut lirik lagu Himalaya Maliq D’Essentials yang akan dibahas maknanya.

\section{Bait I}

\section{Coba khayalkan sejenak// Sepuluh tahun nanti hidupmu// Coba bayangkan sejenak// Misalkan ada aku// Yang menemani hari demi hari yang tak terhitung//}

Bait lagu ini menghasilkan makna sesungguhnya sesuai dengan teori Barthes. Maka dari itu, pemaknaan denotasi pada bait ini disesuaikan dengan apa adanya. Makna denotasi pada lagu ini yaitu menjelaskan bahwa penulis meminta untuk membayangkan sesuatu yang belum terjadi dalam sepuluh tahun mendatang sekaligus membayangkan penulis menemani setiap hari dalam waktu yang belum tentu. Alasan pemaknaan ini dikatakan denotasi dikarenakan adanya penafsiran ungkapan makna sesuai dengan apa yang tertulis pada lagu. Bait pertama meminta kita untuk mencoba membayangkan sesuatu dan menghasilkan makna bahwa penulis lagu meminta kita membayangkan apa yang tertulis pada lagu tersebut.

Makna konotasi pada bait ini juga dibutuhkan bantuan emosi kita untuk menerjemahkan makna yang tak terlihat berupa makna kiasan. Makna konotasi pada lagu ini menjelaskan sebuah ungkapan keinginan penulis untuk membayangkan sepuluh tahun ke depan ada dirinya yang selalu menemani dalam waktu tak terhitung bermakna waktu yang tak terbatas. Artinya, penulis menginginkan agar terbesit dipikiran mengenai kejadian di masa yang akan datang yaitu sepuluh tahun lagi penulis akan menemani masa depan dalam waktu yang tak terbatas. Alasan dikatakan pemaknaan ini merupakan makna konotasi karena ada unsur interpretasi melalui emosi yang dimiliki dengan memaknai bukan yang tertulis apa adanya dan memaknai bahwa bait pertama berisikan kalimat berandai - andai dengan berkhayal di masa depan. Penulis berandai - andai akan menemani seseorang di masa depannya. Penulis mengajak pendengar membayangkan kejadian di masa depan dengan adanya seseorang yang menemani untuk menghabiskan waktu bersama selamanya dengan penggunaan kalimat "hari demi hari yang tak terhitung”.

\section{Bait II}

\section{//Misalkan itu aku yang terakhir untukmu//}

Pemaknaan denotasi pada bait lirik lagu ini masih memiliki makna seperti bait pertama tentang membayangkan sesuatu dengan membayangkan "aku" sebagai penyebutan si penulis 
lagu menjadi yang terakhir untuk seseorang. Ini dapat dijelaskan oleh teori yang disampaikan Barthes, bahwa denotasi mengacu pada suatu petanda tunggal, tidak seperti makna konotasi yang bersifat umum, global dan teersebar. Itulah sebabnya disimpulkan bahwa makna dari bait kedua lirik lagu ini pengandaian atau bayangan dari "aku". Ini terlihat dari penggunaan kata "misalkan" dalam lirik lagu tersebut. (Barthes, 1968:130).

Kajian makna konotasi pada bait lagu ini berupa ungkapan penulis mengenai keinginannya untuk seseorang membayangkan dirinya akan menjadi sosok yang terakhir dalam hidup seseorang tersebut. Bait lagu ini juga masih tentang andai - andai yang dilakukan penulis lagu tentang dirinya dengan seseorang di masa yang akan datang. Alasan pemaknaan ini merupakan makna denotasi karena menampilkan makna dengan apa adanya yang tertulis pada lagu dan alasan pemaknaan konotasi pada bait ini juga mengartikan lagu dengan makna tersirat yang dijelaskan melalui emosi.

\section{Bait III}

\section{//Untuk itu 'kan kupersembahkan// Himalaya Bahkan akan aku taklukkan// //Tanpa cahaya di kegelapan Berbalutkan pelita hatimu//}

Makna denotasi pada bait lagu ini yaitu penulis memberikan Himalaya sebagai persembahan kepada seseorang lalu penulis akan menghadapi puncak tertinggi tersebut tanpa bantuan cahaya sekalipun hanya ditemani oleh hati seseorang. Himalaya yang akan ditaklukkan oleh penulis adalah tempat-tempat gunung tertinggi yang ada di dunia. Pernyataan tersebut merupakan alasan pemaknaan dari makna denotasi dengan menampilkan apa adanya Himalaya pada kenyataannya.

Makna kiasan atau makna konotasi pada bait ini memberikan ungkapan penulis akan menunjukkan usahanya dalam menghadapi keinginannya . Makna tanpa cahaya di kegelapan memiliki ungkapan bahwa tidak ditemui solusi dalam usahanya menghadapi keinginannya, ia akan terus melaluinya demi seseorang karena meskipun begitu penulis beranggapan seseorang tersebut adalah solusi itu sendiri dan jadi alasannya untuk terus berusaha. Anggapan penulis itu terlihat dari ungkapan makna dari kalimat "berbalutkan pelita hatimu"bermakna hati seseorang tersebut sebagai alasannya atau sebagai solusi dalam setiap usaha yang dilakukannya. Memaknai setiap ungkapan ini merupakan hasil dari ungkapan emosi yang tertuang menjadi sebuah makna kiasan, penggunaan emosi ini merupakan wujud dari makna konotasi.

Bait ini berisikan kegigihan penulis dengan menjadikan Himalaya sebagai kesungguhannya. Himalaya disini memiliki kesan berlebihan. Maka dari itu, kata Himalaya yang akan ditaklukkan penulis juga merupakan salah satu contoh dari majas hiperbola. Penulis berusaha meyakinkan seseorang dalam perkataannya. Jika dilihat lagi pada bait ini, penulis hanya membutuhkan hati seseorang dalam memperjuangkan masa depannya dengan seseorang tersebut.

\section{Bait IV}

\section{//Di aku, di aku, dan kamu// Pasti kan kau melihat aku// Saat ku gapai puncak tertinggi// Bersama tujuh warna pelangi//}

Makna denotasi pada bait lagu ini menggunakan pengulangan kata aku kemudian melibatkan seseorang untuk melihatnya saat mencapai puncak tertinggi dengan penuh keyakinan dan ditemani tujuh warna pelangi. Pelangi merupakan lengkung spectrum warna di 
langit yang memiliki warna yang beraneka macam. Tujuh warna pelangi yaitu merah, jingga, kuning, hijau, biru, nila dan ungu. Pemaknaan denotasi pada bait ini menjadikan pelangi sebagai objek yang akan di gapai saat mencapai puncak tertinggi. Pemaknaan tersebut merupakan makna konotasi dengan menfasirkan makna sesuai dengan apa yang tampak dengan mengartikan seseorang mencapai puncak tertinggi kemudian ada pelangi saat mencapai puncak tersebut.

Sedangkan kata pelangi dalam makna kiasan bermakna cukup luas dan pemaknaan pelangi pada bait lagu ini merupakan perasaan yang cukup beragam. Maka dari itu, pemaknaan konotasi pada bait ini yaitu ungkapan keyakinan dari seseorang saat dia telah mencapai keinginannya maka ia akan ditemani perasaan yang beragam disana. Perasaan yang beragam tersebut bisa senang, sedih, kecewa, gelisah, haru dan perasaan lainnya. Saat penulis mencapai keinginannya tentu ada perasaan bahagia saat ia telah sampai dan pasti ada rasa lelah saat ia mencoba mencapai keinginannya. Namun, rasa kebahagiaan adalah yang paling dirasakan ketika keinginan kita tercapai. Memaknai bait ini dengan cakupan yang cukup luas mengakibatkan adanya makna tambahan yang menggunakan perasaan dan dapat dikatakan bahwa makna ini merupakan makna konotasi.

\section{Bait V}

\section{//Misalkan semua terjadi// Meski belum terjadi sekarang// Kita renungkan sejenak// Cara agar semua bisa terjadi//}

Makna denotasi pada bait ini mengungkapkan kalimat pengandaian yaitu kata "misalkan" penulis mencoba berandai seperti bait satu dan dua dengan menghayalkan masa depan agar semua keinginannya terjadi di masa depan. Kalimat pengandaian itu merupakan kalimat yang digambarkan secara jelas pada lagu. Hal ini menjadikan alasan bahwa makna ini merupakan makna denotasi karena mengungkapkan makna sesuai dengan apa yang terlihat jelas. Sedangkan makna konotasinya yaitu ada keinginan penulis untuk membayangkan sesuatu yang belum terjadi saat sekarang sekaligus memikirkan keinginannya untuk tercapai di masa yang akan datang. Bait ini berisikan keinginan di masa depan. Penafsiran bahwa ada keinginan seseorang di masa depan merupakan hasil yang ditangkap oleh peneliti lewat perasaannya dan menjadi alasan makna ini merupakan makna konotasi karena adanya penggunaan nilai rasa dalam menafsirkan makna. Cara pemaknaan bait ini sama dengan bait pertama juga bait kedua.

\section{Bait VI}

\section{//Walau kutahu tak semudah itu//Tapi coba sekali lagi bayangkan aku//}

Makna denotasi pada bait ini yaitu penulis mengetahui bahwa keinginannya tidak mudah dan meminta agar membayangkan dirinya sekali lagi. Membayangkan disini adalah bermakna menggambarkan dalam pikiran. Alasan pemaknaan denotasi pada bait ini karena peneliti mengungkapkan makna sesuai dengan kenyataan yang tertulis pada bait ini. Sedangkan pemaknaan konotasi pada bait lagu ini adalah penulis sadar akan masa depan yang dibayangkannya tidak mudah untuk terjadi, penulis masih memiliki keinginan untuk dibayangkan dirinya menandakan ia tidak mudah menyerah meskipun hal yang dibayangkannya adalah hal yang sulit. Penafsiran makna tambahan menggunakaan perasaan ini memunculkan makna baru mengenai kesadaran dan keinginan penulis lagu merupakan sebab dikatakannya makna ini merupakan makna konotasi.

Bait selanjutnya terjadi pengulangan lirik lagu dengan kembali kepada bait pertama dan begitu selanjutnya. Bait pertama hingga bait keenam menampilkan ungkapan keinginan 
penulis untuk membayangkan sesuatu mengenai masa depan. Makna "Himalaya" sebagai puncak tertinggi bermakna kias sebuah keinginan yang cukup besar yang ditampilkan penulis dalam bait lagunya.

\section{Tabel 1. Pembahasan Makna Konotasi dan Denotasi Pada Lirik Lagu "Himalaya" karya Maliq D’Essentials}

\begin{tabular}{|c|c|c|}
\hline Lirik Lagu & Makna Denotasi & Makna Konotasi \\
\hline $\begin{array}{l}\text { Coba khayalkan sejenak } \\
\text { Sepuluh tahun nanti } \\
\text { hidupmu } \\
\text { Coba bayangkan sejenak } \\
\text { Misalkan ada aku Yang } \\
\text { menemani hari demi hari } \\
\text { yang tak terhitung }\end{array}$ & $\begin{array}{l}\text { Membayangkan sesuatu yang } \\
\text { belum terjadi dalam sepuluh tahun } \\
\text { mendatang sekaligus } \\
\text { membayangkan penulis menemani } \\
\text { setiap hari dalam waktu yang } \\
\text { belum tentu. }\end{array}$ & $\begin{array}{l}\text { Keinginan penulis } \text { untuk } \\
\text { membayangkan sepuluh tahun ke } \\
\text { depan ada dirinya yang selalu } \\
\text { menemani dalam waktu tak terhitung } \\
\text { bermakna waktu yang tak terbatas. }\end{array}$ \\
\hline $\begin{array}{l}\text { Misalkan itu aku yang } \\
\text { terakhir untukmu }\end{array}$ & $\begin{array}{l}\text { Membayangkan menjadi bagian } \\
\text { terakhir dalam hidup seseorang. }\end{array}$ & $\begin{array}{l}\text { Keinginan seseorang membayangkan } \\
\text { dirinya akan menjadi sosok yang } \\
\text { terakhir dalam hidup seseorang } \\
\text { tersebut. }\end{array}$ \\
\hline \begin{tabular}{|l} 
Untuk itu 'kan \\
kupersembahkan, Himalaya \\
Bahkan akan aku taklukkan \\
Tanpa cahaya di kegelapan \\
Berbalutkan pelita hatimu
\end{tabular} & $\begin{array}{l}\text { Himalaya sebagai persembahan } \\
\text { kepada seseorang dengan } \\
\text { menghadapi puncak tertinggi } \\
\text { tersebut tanpa bantuan cahaya } \\
\text { sekalipun, hanya membutuhkan } \\
\text { hati seseorang. }\end{array}$ & $\begin{array}{l}\text { Menunjukkan usaha seseorang untuk } \\
\text { mendapatkan keinginannya. } \\
\text { Makna } \\
\text { tanpa cahaya di kegelapan memiliki } \\
\text { ungkapan bahwa tidak ditemui solusi } \\
\text { dalam usahanya menghadapi } \\
\text { keinginannya, ia akan terus } \\
\text { melaluinyademi seseorang. Makna } \\
\text { Berbalutkan pelita hatimu bermakna } \\
\text { bahwa menjadikan hati seseorang } \\
\text { sebagai alasannya menempuh } \\
\text { keinginannya. }\end{array}$ \\
\hline $\begin{array}{l}\text { Di aku, di aku, dan kamu } \\
\text { Pasti kan kau melihat aku } \\
\text { Saat ku gapai puncak } \\
\text { tertinggi } \\
\text { Bersama tujuh warna } \\
\text { pelangi }\end{array}$ & $\begin{array}{l}\text { Meminta seseorang untuk } \\
\text { melihatnya saat mencapai puncak } \\
\text { tertinggi dengan penuh keyakinan } \\
\text { dan ditemani tujuh warna pelangi. } \\
\text { Pelangi merupakan lengkung } \\
\text { spectrum warna di langit yang } \\
\text { memiliki warna yang beraneka } \\
\text { macam. Tujuh warna pelangi yaitu } \\
\text { merah, jingga, kuning, hijau, biru, } \\
\text { nila dan ungu }\end{array}$ & $\begin{array}{l}\text { Ungkapan keyakinan dari seseorang } \\
\text { saat dia telah mencapai keinginannya } \\
\text { maka ia akan ditemani perasaan yang } \\
\text { beragam disana. Perasaan yang } \\
\text { beragam tersebut bisa senang, sedih, } \\
\text { kecewa, gelisah, haru dan perasaan } \\
\text { lainnya }\end{array}$ \\
\hline $\begin{array}{l}\text { Misalkan semua terjadi } \\
\text { Meski belum terjadi } \\
\text { sekarang Kita renungkan } \\
\text { sejenak Cara agar semua } \\
\text { bisa terjadi }\end{array}$ & $\begin{array}{l}\text { Berandai menghayalkan masa } \\
\text { depan agar semua keinginannya } \\
\text { terjadi di masa depan. }\end{array}$ & $\begin{array}{l}\text { Keinginan membayangkan sesuatu } \\
\text { yang belum terjadi saat sekarang } \\
\text { sekaligus memikirkan keinginannya } \\
\text { untuk tercapai di masa yang akan } \\
\text { datang. }\end{array}$ \\
\hline
\end{tabular}




\begin{tabular}{|l|l|l|l|}
\hline Walau kutahu tak semudah & Keinginannya tidak mudah dan & Penulis sadar akan masa depanyang \\
itu & meminta agar membayangkan & dibayangkannya tidak mudah untuk \\
Tapi coba sekali lagi & dirinya lagi. & terjadi, penulis masih memiliki \\
bayangkan aku & Membayangkan disini adalah & keinginan untuk dibayangkan dirinya \\
& bermakna menggambarkan dalam & menandakan ia tidak mudah \\
pikiran. & menyerah meskipun hal yang \\
& & dibayangkannya adalah hal yang sulit. \\
\hline
\end{tabular}

Pemaknaan denotasi dan konotasi pada lagu 'Himalaya' karya Maliq D’Essentials seperti apa yang telah dijabarkan di atas memiliki tujuan dalam setiap ungkapan maknanya. Tujuan pengggunaan makna denotatif dan konotatif dalam lagu 'Himalaya' disesuaikan dengan tujuan kehidupan sehari-hari. Barthes menggunakan konsep sintagmatik dan paradigmatik dalam menjelaskan gejala budaya, salah satunya karya sastra (Nurdiansyah, 2018). Lagu merupakan salah satu budaya yang ada di sekitar dan bait pada lagu termasuk karya sasra. Oleh karena itu, tujuan penggunaan makna denotatif dan konotatif dalam lagu untuk menafsirkan bait lagu 'Himalaya' yang dikaitkan dengan budaya yang ada di sekitar kita berupa kenyataan dalam kehidupan sehari-hari mengenai perjuangan seseorang setinggi Himalaya. Tujuan penelitian ini sejalan dengan hasil temuan penelitian lainnya yang menafsirkan teks ataupun tanda dikaitkan dengan nilai-nilai budaya, ideologi, moral, dan spiritual dalam mengungkapkan makna lagu Zona Nyaman Fourtwenty (Nurdiansyah, 2018).

\section{Simpulan}

Penjabaran makna denotasi dan konotasi pada lagu Himalaya dari Maliq D’Essentials sebagai permasalahan yang akan dibahas pada penelitian ini. Serelah ditelusuri pemaknaan denotasi dengan apa yang tampak dari Himalaya berupa puncak tertinggi,sedangkan konotasi dengan apa yang tersembunyi menggunakan perasaan penulis berupa usaha seseorang yang giat dalam mencapai keinginannya. Aspek pemaknaan konotasi dan denotasi pada lagu Himalaya dari Maliq D'Essentials menghasilkan beberapa temuan. Beberapa temuan penelitian sebagai berikut.

Denotasi pada lirik lagu Himalaya dari Maliq D’Essentials bermakna sesuai dengan apa adanya dari yang tertulis pada lagu tersebut. Secara keseluruhan makna denotasi pada lagu ini mengungkapkan keinginan penulis untuk membayangkan kejadian di masa depan. Lagu Himalaya ini menampilkan kalimat berandai-andai yang cukup banyak. Pemaknaan lagu ini membayangkan keinginan penulis bersama seseorang saat di masa depan nanti.

Pemaknaan konotasi pada lagu ini yaitu ungkapan penulis yang bisa menghadapi cobaan terbesar apapun, ia akan tetap menghadapinya karena seseorang menjadi alasan ia untuk tetap membayangkan sekaligus menghadapi kejadian sekarang untuk masa depan. Pemilihan kata "Himalaya" sebagai cobaan terbesar yang ditulis penulis yang harus dihadapi demi keinginannya dalam jangka masa yang akan datang.

Temuan penelitian ini mencoba menafsirkan bait lagu menggunakan logika sekaligus perasaan yang memiliki maksud untuk memecahkan pemaknaan denotasi dan konotasi pada lagu Himalaya Maliq D'Essentials. Alasan pemilihan kata "Himalaya" ini bisa kita lihat dari arti kata itu sendiri bahwa Himalaya merupakan puncak tertinggi dan untuk menggapainya merupakan hal yang sulit. Maka dari itu, penulis menggunakan Himalaya sebagai sesuatu yang sulit digapai dianalogikan sebagai keinginan yang sulit untuk dihadapi penulis. Hal ini memberikan penggambaran bahwa penulis memiliki keinginan yang besar sekaligus usahanya yang besar juga. 


\section{Referensi}

Antika, T. R., Ningsih, N., \& Sastika, I. (2020). Analisis Makna Denotasi, Konotasi, Mitos Pada Lagu "Lathi” karya Weird Genius. ASAS: Jurnal Sastra. 9(2): 61-71

Awe, M. (2003). "Iwan Fals Nyanyian di Tengah Kegelapan". Skripsi. Surakarta: UNS.

Barthes, R. (2017). Elemen-Elemen Semiologi. (Terj. Ardiansyah). Yogyakarta : Basabasi

Budiman, R. F., \& Christin, M. (2021). Analisis Semiotika Roland Barthes Pada Lirik Dan Video Lagu Peradaban Karya Grup Band Feast. eProceedings of Management, 8(2).

Chaer, Abdul. Pengantar Semantik Bahasa Indonesia. (2009). Jakarta: Rineka Cipta.

Darmawati, U. (2019). Semantik: Menguak Makna Kata. Bandung: Pakar Raya.

Dewi, Wendi Widya Ratna. (2010). Semantik Bahasa Indonesia. Klaten: PT. Intan Pariwara.

Fitri, N., Sobari, T., Kamaluddin, T. (2020). Majas dan Makna Pada Lirik Lagu Nadin Amizah yang Berjudul "Seperti Tulang". Parole. 3(5): 785-796

Hoed, B. H. (2011). Semiotik \& Dinamika Sosial Budaya. Depok: Komunitas Bambu.

Kusumawati, H. S., Rahayu, N. T., \& Fitriana, D. (2019). Analisis Semiotika Model Roland Barthes pada Makna Lagu "Rembulan" Karya Ipha Hadi Sasono. Klitika: Jurnal Ilmiah Pendidikan Bahasa dan Sastra Indonesia, 1(2).

Luxemburg, J. V., Bal, M., \& Weststeijn, W. G. (1984). Pengantar Ilmu Sastra (terj. Dick Hartoko). Jakarta: PT. Gramedia.

Natanael, A, \& Sannie, A. W. (2018). Analisis Semiotika Makna Kesendirian Pada Lirik Lagu "Ruang Sendiri" Karya Tulus. Jurnal Semiotika. 19(2): 107-117

Nirmala, A. A., \& Anwar, S. (2020). Interpretasi Lagu-Lagu Nadin Amizah (Album Selamat Ulang Tahun): Kajian Semiotika. Jurnal Sasando. 3(2): 13-22

Nurdiansyah, C. (2018). Analisis Semiotik Makna Motivasi Berkarya Lirik Lagu Zona Nyaman Karya Fourtwnty, Jurnal Komunikasi. 9(2): 161-167

Pradopo, R. D. (2010). Pengkajian puisi: analisis strata norma dan analisis struktural dan semiotik. Yogyakarta: UGM Press.

Rusmana, D. (2014). Filsafat Semiotika: Paradigma, Teori, dan Metode Interpretasi Tanda. Bandung: Pustaka Setia.

Rustandi, A., Triandy, R., \& Harmaen, D. (2020). Analisis Semiotika Makna Kerinduan Pada Lirik Lagu "Hanya Rindu" Karya Andmesh Kamaleng. Metabasa: Jurnal Bahasa, Sastra, dan Pembelajaran, 2(2). 64-71.

Septiana, R. (2019). Makna Denotasi, Konotasi, dan Mitos dalam Film "Who Am I Kein System Ist Sicher", Skripsi, Universitas Sam Ratulangi.

Sii, P., \& Jatam, S. (2019). Makna Lirik Lagu Manggarai Karya Daniel Anduk dalam Album Weong Nai (Kajian Semiotika Roland Barthes). PROLITERA: Jurnal penelitian pendidikan, bahasa, sastra, dan budaya, 2(2), 60-74.

Suhardi. (2015) Dasar-dasar Ilmu Semantik. Yogyakarta: Ar - Ruzz Media.

Sylado, R. (1983). Menuju Apresiasi Musik. Bandung : Angkasa.

Ullmann, S. (2012) Pengantar Semantik (terj. Sumarsono). Yogyakarta: Pustaka Belajar. 